\title{
Specify Another Form of Birth Control that was Used
}

National Cancer Institute

\section{Source}

National Cancer Institute. Specify Another Form of Birth Control that was Used. NCI

Thesaurus. Code C160256.

A directive to specify another form of birth control that was used. 